\title{
STRATEGI PENGEMBANGAN INDUSTRI KREATIF BANDUNG OLEH PEMERINTAH KOTA BANDUNG DALAM MENGANTISIPASI IMPLEMENTASI ASEAN FREE TRADE AREA DAN ASEAN ECONOMIC COMMUNITY
}

Mariane Olivia Delanova K.

\begin{abstract}
ASEAN Free Trade Area (AFTA) and ASEAN Economic Community (AEC) has been implemented since 2015. Itv means ASEAN make a step into a new era, called free trade era, which is reducing all trade barriers, include tariff and non tarrif barriers. ASEAN has a vision by implementing AFTA and EAC, to make Southeast Asia region can improve its economic sector, also improving economic sector of its member states, and so Indonesia. This research focuses on the strategic of Pemerintah Kota Bandung (The Local Government of Bandung City) to develop and improve the creative industries of Bandung City, especially in the era of AFTA and AEC. Also this research will explore the obstacles of creative industries of Bandung City in the era of AFTA and AEC. Creative industries of Bandung City have to reach the benefit from the implementing of AFTA and AEC, so creative industries of Bandung City will contribute to Indonesia's national income, especially increasing Bandung City's income.
\end{abstract}

Keywords: ASEAN Free Trade Area, ASEAN Economic Community, Creative Industries of Bandung City. 


\section{Pendahuluan}

Perkembangan situasi di tataran global dan regional pada saat ini membutuhkan strategi yang tepat dalam mengantisipasi dinamika dan perubahan yang cepat. Globalisasi termasuk globalisasi ekonomi menjadi dinamika internasional yang membutuhkan fokus luar biasa bagi setiap negara, tidak terkecuali Indonesia. Indonesia merupakan negara yang terletak di kawasan Asia Tenggara, bergabung ke dalam Association Southeast Asian Nations (ASEAN). ASEAN dibentuk pada 8 Agustus 1967 dan menjadi organisasi internasional setelah berhasil menandatangani ASEAN Charter. Pada saat ini, terjadi perkembangan yang pesat di ASEAN. Salah satu perkembangan yang terjadi di dalam ASEAN adalah dengan diwujudkannya ASEAN Community yang diberlakukan sejak tahun 2015. ASEAN Community didasarkan atas tiga pilar, yaitu ASEAN Economic Community, ASEAN PoliticalSecurity Community dan ASEAN Socio-Culture Community.

Salah satu pilar yaitu ASEAN Economic Community (AEC) atau Masyarakat Ekonomi ASEAN bertujuan untuk mewujudkan pasar tunggal (single market) dan basis produksi melalui aliran barang, jasa, investasi, modal dan tenaga kerja terlatih. Selain itu, AEC bertujuan untuk lingkungan yang mendukung perkembangan dunia bisnis/ekonomi dan lingkungan regional yang mendukung inovasi dengan mengadopsi kerangka kebijakan bersama, seperti membuat standarisasi dan kerjasama bersama dalam berbagai bidang. AEC juga berupaya untuk meningkatkan keterhubungan 
dalam transportasi dan berbagai infrastruktur lainnya. Selanjutnya, AEC juga bertujuan untuk meraih pembangunan ekonomi yang cepat melalui insiatif kreatif yang mendorong unit usaha kecil dan menengah (UMKM) untuk dapat bersaing dalam perekonomian baik di tingkat regional dan global. Satu hal lagi yang diperhatikan dalam AEC adalah upaya untuk membangun kapasitas Negara-negara anggota yang baru bergabung ke ASEAN untuk memastikan integrasi negaranegara anggota tersebut ke dalam AEC. AEC juga memiliki visi agar ASEAN pada akhirnya dapat bergabung ke dalam perekonomian global melalui hubungan ekonomi dengan pihak eksternal (ASEAN, ASEAN Economic Community, 2015).

Jika AEC bertujuan mewujudkan perekonomian yang mengglobal di antara negara-negara ASEAN dan untuk meningkatkan daya saing ekonomi di kawasan regional ASEAN. ASEAN Free Trade Area (AFTA) merupakan kesepakatan bersama antara negara-negara ASEAN untuk membentuk kawasan perdagangan bebas. Tujuan utamanya adalah untuk meningkatkan daya saing ekonomi dan bisnis ASEAN di kancah dunia. Visi AFTA menjadikan negaranegara ASEAN bisa menjadi basis produksi dunia. Dengan implementasi kebijakan perdagangan bebas AFTA ini, diharapkan tidak ada hambatan tariff, karena ada penurunan bea masuk, menjadi hanya sekitar 0-5\%.Penurunan dan penghapusan tidak saja persoalan hambatan tariff, tetapi juga hambatan non-tariff terutama untuk negara anggota ASEAN. Skema Common Effective Preferential Tariffs For 
ASEAN Free Trade Area (CEPT-AFTA) adalah skema untuk mengimplementasikan AFTA melalui penurunan tarif hingga menjadi 0-5\%, penghapusan pembatasan kuantitatif dan hambatan-hambatan non-tarif lainnya (GT Suroso dan Widyaiswara, Masyarakat Ekonomi ASEAN dan Perekonomian Indonesia, 2018). AFTA sendiri telah disepakati untuk dapat diimplementasikan di ASEAN sejak tahun 2015.

Kota Bandung merupakan sebuah kota di provinsi Jawa Barat, Indonesia, yang juga menjadi ibukota provinsi Jawa Barat (Jabar). Kota Bandung merupakan salah satu destinasi wisata di Indonesia karena Bandung memiliki udara yang sejuk dan pemandangan alam yang luar biasa. Oleh sebab itu, tidak mengherankan jika industri kreatif berkembang pesat di Bandung sebagai dampak dari bidang pariwisata Bandung yang menjanjikan dan menarik banyak wisatawan, baik wisatawan mancanegara maupun wisatawan domestik untuk berkunjung ke Bandung. United Nations Educational, Scientific and Cultural Organization (UNESCO) bahkan mengumumkan Kota Bandung sebagai salah satu kota dalam jaringan kota kreatif UNESCO (Creative Cities Network). Pengumuman tersebut disampaikan Direktur Jenderal (Dirjen) UNESCO, Irina Bokova, Bokova mengumumkan penunjukkan 47 kota yang berasal dari 33 negara sebagai anggota baru dari UNESCO Creative Cities Network di Paris, pada tanggal 11 Desember 2015 (Antara News, UNESCO Umumkan Bandung dalam Jaringan Kota Kreatif, 2015). 
Melihat faktor-faktor yang dijelaskan di atas, Pemerintah Kota Bandung memiliki keinginan untuk memajukan dan mengembangkan industri kreatif di Kota Bandung, tidak hanya berhenti sampai menjadikan Kota Bandung sebagai ikon kota kreatif. Kreatifitas dan inovasi menjadi asset yang lebih berharga apabila dibandingkan dengan sumber daya ekonomi lainnya. Oleh sebab itu, perlu dilakukan penelitian mengenai kebijakan Pemerintah Kota Bandung mengenai kebijakan yang berhubungan dengan industri kreatif, terutama dalam era implementasi AFTA dan EAC. Pada perkembangan regional Asia Tenggara saat ini, maka Indonesia khususnya Pemerintah Kota Bandung membutuhkan paradigma baru dalam penyusunan dan pembuatan kebijakan industri kreatif yang dapat mengadopsi perkembangan tersebut karena apabila pengembangan industri kreatif dilakukan dengan optimal, maka akan menjadi pemasukan daerah yang menjanjikan.

\section{Kerangka Konseptual / Teoritis}

\section{Pendekatan Liberalis}

Penelitian ini menggunakan pendekatan liberalis. Kaum liberal umumnya mengambil positif tentang sifat manusia. Mereka memiliki keyakinan besar terhadap akal pikiran manusia dan mereka yakin bahwa prinsip-prinsip rasional dapat dipakai pada masalah-masalah internasional. Kaum liberal mengakui bahwa individu selalu mementingkan diri 
sendiri dan bersaing terhadap suatu hal. Namun, mereka juga percaya bahwa individu-individu memiliki banyak kepentingan dan dengan demikian dapat terlibat dalam aksi sosial yang kolaboratif dan kooperatif, baik domestik maupun internasional yang menghasilkan manfaat besar bagi setiap orang baik di dalam negeri maupun luar negeri. Namun, kaum liberal sepakat bahwa dalam jangka panjang kerjasama yang didasarkan pada kepentingan timbal balik akan berlaku. $\mathrm{Hal}$ itu disebabkan modernisasi yang terus menerus meningkatkan ruang lingkup dan kebutuhan bagi kerjasama (Robert Jackson dan Georg Sorensen, Pengantar Studi Hubungan Internasional: Teori dan Pendekatan, 2013).

Liberalisme menempatkan negara sebagai suatu manifestasi kebutuhan untuk melindungi kebebasan individual. Dalam paradigmanya, terdapat beberapa asumsi yang dapat digunakan untuk menganalisis fenomena yang akan diteliti. Asumsi-asumsinya adalah sebagai berikut:

1. Menekankan pada kerjasama antar negara

2. Pandangan positif terhadap sifat alamiah manusia

3. Negara bukan satu-satunya aktor dalam Hubungan Internasional.

Kepercayaan penuh terhadap fungsi dari organisasi dan hukum internasional untuk mengatasi sistem 
internasional yang anarki. Interaksi antar aktor-aktor tidak hanya terbatas pada aspek politik (high politics) tetapi juga pada aspek ekonomi (low politics). Peneliti menggunakan pendekatan ini disebabkan penelitian yang dilakukan mengenai strategi pengembangan industri kreatif di Kota Bandung, di dalam pelaksanaannya tidak hanya melibatkan aktor negara saja, yaitu Pemerintah Pusat dan Pemerintah Kota Bandung, tetapi melibatkan juga berbagai aktor nonnegara, diantaranya para pelaku industri kreatif. Kemudian interaksi antar aktor-aktor terkait pada aspek ekonomi (low politics), yakni ekonomi kreatif yang didalamnya terdapat industri kreatif sebagai pengejawantahannya, bukan persoalan yang high-politics sifatnya. Hal ini sesuai dengan asumsi dari pendekatan liberalis. Pendekatan liberalis dianggap dapat mempermudah peneliti dalam mendeskripsikan dan menganalisis strategi pengembangan industri kreatif di Kota Bandung (2015-2017).

\section{Konsep Kerjasama Internasional}

Salah satu pola interaksi dalam hubungan internasional adalah kerjasama. Dalam hubungan internasional dikenal apa yang dinamakan kerjasama internasional yang didalamnya bertemu berbagai macam kepentingan nasional dari berbagai negara dan bangsa yang tidak dapat dipenuhi di dalam negerinya sendiri. Kerjasama internasional dapat terbentuk karena kehidupan internasional yang meliputi berbagai bidang seperti ideologi, politik, ekonomi, sosial, lingkungan hidup, 
kebudayaan, pertahanan, dan kemananan (Anak Agung Banyu Perwita dan Yanyan Mochamad Yani, Pengantar Ilmu Hubungan Internasional, 2006). Selain melihat kerjasama internasional berdasarkan bidangnya, kerjasama internasional juga dapat dilihat berdasarkan sifatnya yakni kerjasama yang bersifat bilateral, trilateral dan multilateral.

"kerjasama internasional adalah suatu bentuk interaksi dari suatu negara dengan negara atau kelompok negara lain yang sama-sama memiliki kepentingan untuk merealisasikan kepentingan dan kebutuhan nasional masing-masing dengan memahami ketentuan yang telah disepakati sebelumnya. Dengan kata lain, kerjasama internasional merupakan bentuk interaksi yang ruang lingkupnya melintasi batas-batas negara dengan tujuan untuk mencapai kepentingan yang telah disepakati baik antar pemerintah maupun non pemerintah" (Anak Agung Banyu Perwita dan Yanyan Mochamad Yani, Pengantar Ilmu Hubungan Internasional, 2006).

Terdapat tiga tingkatan kerjasama internasional (Brian Hocking dan Michael Smith, World Politics: An Introduction To International Relations, 1990), yaitu:

1. Konsensus, merupakan suatu tingkat kerjasama yang ditandai oleh sejumlah ketidakhirauan kepentingan diantara negara-negara yang terlibat dan tanpa keterlibatan yang tinggi di antara negara-negara yang terlibat.

2. Kolaborasi, merupakan suatu tingkat kerjasama yang lebih tinggi dari konsensus dan ditandai oleh 
sejumlah besar kesamaan tujuan, saling kerjasama yang aktif diantara negara-negara yang terjalin hubungan kerjasama dalam memenuhi kepentingan masing-masing.

3. Integrasi, merupakan kerjasama yang ditandai dengan adanya kedekatan dan keharmonisan yang sangat tinggi diantara negara-negara yang terlibat. Dalam integrasi jarang sekali terjadinya benturan kepentingan diantara negara-negara yang terlibat.

Kerjasama internasional merupakan kerjasama yang umumnya dilakukan oleh beberapa negara yang sama-sama saling menguntungkan. Kerjasama internasional harus bersifat harmonis dan menguntungkan bagi yang terlibat di dalamnya. Konsep kerjasama internasional ini digunakan untuk menganalisis strategi pengembangan industri kreatif yang dilakukan Pemerintah Kota Bandung dalam tataran praktisnya, melibatkan kerjasama antara Indonesia dengan aktor negara dan non-negara di luar wilayah Indonesia.

\section{Konsep Diplomasi Publik}

Istilah diplomasi publik pertama kali diperkenalkan pada tahun 1965 oleh Edmund Gullion dalam Fletcher School of Law and Diplomacy di Tuffs University. Konsep diplomasi publik adalah proses komunikasi pemerintah terhadap publik internasional yang bertujuan untuk memberikan pemahaman ataupun informasi mengenai sebuah negara, budaya, 
kepentingan nasional ataupun kebijakan negara tersebut. Melalui diplomasi publik ini, opini publik dapat berperan dalam mendukung kebijakan negara. Tidak hanya itu, publik dalam hal ini juga dapat mempengaruhi opini masyarakat negara-negara lain mengenai negaranya (Papp, S Daniel, Contemporary International Relations, Frameworks for Understanding, 1997) Implementasi diplomasi publik dapat dilihat dari hierarki aktifitas yang dijalankan (Tonny Dian Effendi, Diplomasi Publik Jepang, Perkembangan dan Tantangan, 2011). Dengan kata lain, dalam pelaksanaan diplomasi publik ini memiliki aktifitas yang berbeda-beda. Tahapan pertama adalah diplomasi dijalankan dengan tujuan paling mendasar, yaitu meningkatkan pengetahuan publik atau dunia internasional tentang keberadaan negara tersebut. Tahapan kedua adalah ketika masyarakat negara lain telah mengenal dan terbiasa dengan keberadaan negara yang bersangkutan, maka harus dilakukan dengan selanjutnya adalah meningkatkan apresiasi terhadap negara tersebut.

Tahapan ketiga adalah menciptakan keterikatan masyarakat negara lain. Meningkatkan keterikatan ini harus ditempuh ketika masyarakat negara lain telah memiliki pandangan positif sehingga kedekatan dengan negaranya tersebut menjadi semakin penting. Ketika ketiga tahapan telah terlampaui, maka tahapan yang terakhir adalah tahap mempengaruhi. Tahapan ini dilakukan dengan banyak cara misalnya: meningkatkan kerjasama dalam bidang pendidikan, pertukaran pelajar dan mahasiswa, memberikan beasiswa, 
penelitian bersama dan lain sebagainya. Kerjasama dalam bidang ekonomi juga menjadi hal yang penting untuk mengikatkan hubungan menjadi lebih erat seperti perjanjian investasi, perdagangan dan lain-lain (Tonny Dian Effendi, Diplomasi Publik Jepang, Perkembangan dan Tantangan, 2011). Berbeda dengan diplomasi tradisional yang identik dengan pola government to government, diplomasi publik lebih mengarah kepada government to people atau bahkan people to people. Diplomasi publik bukan semata-mata hanya aktor publik yang menjalankan proses diplomasi, tetapi aktor publik ini publik yang menjalankan proses diplomasi, tetapi aktor publik ini tetap merupakan bagian atau tetap difasilitasi oleh negara. Konsep diplomasi publik dan negara-negara lain yang melakukan kerjasama dalam pengembangan industri kreatif di Bandung (government to government) maupun kerjasama Pemerintah Kota Bandung dengan para pelaku industri kreatif (people to people).

\section{Konsep Ekonomi Kreatif dan Industri Kreatif}

Ekonomi kreatif merupakan konsep ekonomi baru yang memadukan informasi dan kreatifitas yang mengandalkan ide, gagasan dan pengetahuan dari sumber daya manusia sebagai faktor produksi. Konsep ini didukung oleh keberadaan industri kreatif yang menjadi pengejawantahannya (I Gusti Bagus Arjana, 2015).

Dengan kata lain, ekonomi kreatif digerakkan oleh sektor industri yang disebut industri kreatif (Tim Indonesia Design 
Power Departemen Perdagangan RI, 2008). John Howkins mendefinisikan ekonomi kreatif sebagai the creation of value as a result of idea (I Gusti Bagus Arjana, 2015). Menurut Colette Henry dan Anne de Bruin pada awalnya ruang lingkup pengertian industri kreatif meliputi segala macam industri yang berbasis kreatifitas yang melahirkan Hak Kekayaan Intelektual (HKI), namun kemudian John Howkins mempersempit pengertian industri kreatif menjadi industri yang memiliki keterkaitan erat dengan aspek seni atau budaya (Basuki Antariksa, 2016).

Ditinjau dari aspek akademis, studi mengenai industri kreatif dapat dilakukan setidaknya melalui tiga pendekatan. Pertama, dari aspek budaya, industri kreatif adalah industry yang berkaitan dengan nilai-nilai budaya, seni dan hiburan. Kedua dari Hak Cipta, industri kreatif dilihat sebagai industri yang yang mengandung berbagai aktivitas yang dapat dilindungi oleh Hak Cipta. Ketiga, dilihat dari aspek kreativitas, industri kreatif adalah industri yang sifatnya lintas sektor khususnya adalah yang dijadikan sebagai focus perhatian pemerintah Inggris sebagai negara yang pertama kali mempopulerkan istilah tersebut (Basuki Antariksa, 2016).

Berdasarkan laporan United Nations Conference on Trade and Development (UNCTAD), Creative economy : "A Feasible Development Option", model pengembangan ekonomi kreatif di negara maju maupun negara berkembang dapat dikelompokkan menjadi: UNCTAD Model, World Intellectual Property Organization (WIPO) Copyright Model, Concentric 
Circles Model, Symbolic Texts Model, dan United Kingdom Department of Culture, Media, and Sport Model.

UNCTAD Model mengelompokkan industri kreatif berdasarkan pada kreativitas yang bernilai ekonomi dan memiliki intellectual property. WIPO Copyright Model mengelompokkan industri kreatif berdasarkan pada peran industri kreatif. Peran ini dikelompokkan menjadi core, partial, interdependent dan non-dedicated. Concentric Circles Model mengelompokkan industri kreatif berdasarkan pada porsi budaya dari sebuah produk kreatif, dimana semakin besar konten budayanya maka akan semakin unik. Symbolic Texts Model mengelompokkan industri kreatif berdasarkan pada besar kecilnya pengaruh seni terhadap perkembangan sosial dan politik.

Gambar 1. Model Pengembangan Ekonomi Kreatif

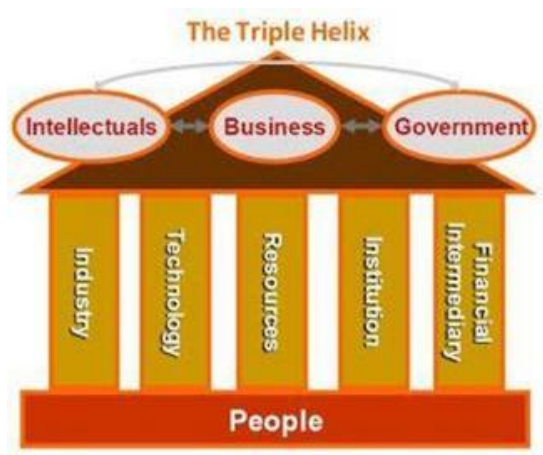

Sumber: Departemen Perdagangan RI (2008)

Pondasi ekonomi kreatif adalah sumber daya insani 
(people) yang merupakan elemen terpenting dalam ekonomi kreatif. Dalam model pengembangan ekonomi kreatif terdapat lima pilar penting yaitu (Tim Indonesia Design Power Departemen Perdagangan RI, 2008):

1. Industry. Industri merupakan bagian dari kegiatan masyarakat yang terkait dengan produksi, distribusi, pertukaran serta konsumsi produk atau jasa dari sebuah negara atau area tertentu. Hal ini berdasarkan kepada pendekatan dari John Howkins yang mengatakan bahwa kreativitas saja tidak bisa dihitung. Yang bisa dihitung adalah produk kreatif.

2. Technology. Richard Florida mengatakan ada tiga modul utama membangun ekonomi berbasis kreativitas yaitu talenta sumber daya insani, teknologi dan toleransi sosial. Teknologi sebagai perangkat (tools) dalam berkreasi, memproduksi, berkolaborasi, mencari informasi, distribusi dan sarana bersosialisasi.

3. Resources. Sumber daya yang dimaksudkan di sini adalah input yang dibutuhkan dalam proses penciptaan nilai tambah, selain ide atau kreativitas yang dimiliki oleh sumber daya insani yang merupakan landasan dari industri kreatif ini.

4. Institution. Institution dalam pilar pengembangan industri kreatif dapat didefinisikan sebagai tatanan 
sosial dimana termasuk di dalamnya adalah kebiasaan, norma, adat, aturan serta hukum yang berlaku.

5. Financial Intermediary. Lembaga intermediasi keuangan adalah lembaga yang berperan menyalurkan pendanaan kepada pelaku industri kreatif yang membutuhkan baik dalam bentuk modal/ekuitas maupun pinjaman/kredit.

Bangunan ekonomi kreatif ini dipayungi oleh hubungan antara cendekiawan (intellectuals), bisnis (business), dan pemerintah (government) yang disebut sebagai sistem triple helix yang merupakan aktor utama penggerak lahirnya kreativitas, ide, ilmu pengetahuan dan teknologi yang vital bagi tumbuhnya industri kreatif. Hubungan yang erat, saling menunjang dan bersimbiosis mutualisme antara ketiga aktor tersebut dalam kaitannya dengan landasan dan pilar-pilar model industri kreatif akan menghasilkan industri kreatif yang berdiri kokoh dan berkesinambungan.

\section{Konsep Implementasi}

Implementasi adalah realisasi, pelaksanaan dan penyelenggaraan sebuah program atau kegiatan tertentu yang telah disusun atau disepakati sebelumnya (Dinas Pendidikan dan Kebudayaan, 1990). Tahapan implementasi perlu dipersiapkan dengan baik pada tahap perumusan. Menurut Birkland, implementasi kebijakan berfokus pada apa yang terjadi pada kebijakan atau program setelah dirumuskan. 
Dalam hal ini implementasi kebijakan berkaitan dengan operasionalisasi perjanjian atau kebijakan bilateral setelah dirumuskan dan disepakati (Piet Thabo Tshetlo, 2018).

Implementasi kebijakan secara konseptual dapat dikatakan sebagai sebuah proses pengumpulan sumber daya alam maupun sumber daya manusia dan diikuti dengan penentuan tindakan-tindakan yang harus diambil untuk mencapai suatu tujuan. Menurut Van Meter dan Van Horn implementasi adalah tindakan-tindakan yang dilakukan baik oleh individu-individu atau pejabat-pejabat atau kelompokkelompok pemerintah atau swasta yang diarahkan pada tercapainya tujuan-tujuan yang telah digariskan dalam keputusan kebijaksanaan (Leo Agustino, 2008). Secara umum definisi implementasi adalah pelaksanaan atau penerapan. Implementasi juga dikaitkan dengan suatu kegiatan yang dilaksanakan untuk mencapai tujuan tertentu.

\section{Konsep Strategi}

Robert M. Grant mendefinisikan strategi sebagai rencana keseluruhan dalam memanfaatkan sumber daya untuk memperoleh kedudukan yang menguntungkan, dan dalam strategi kemenangan adalah segalanya (Robert M Grant, 1997). Strategi memiliki empat elemen yang harus dipenuhi agar tujuan yang ingin dicapai dapat terwujud (Robert M Grant, 1997):

1. Tujuan yang jelas 
2. Pemahaman yang baik mengenai lingkungan eksternal.

3. Penilaian yang objektif mengenai sumber daya yang dimiliki.

4. Pelaksanaan yang efektif.

Strategi harus memiliki tujuan yang jelas untuk mencapai kesuksesan. Dalam membuat strategi juga penting untuk mengetahui kelebihan dan kekuatan, sehingga dapat mengukur tujuan dengan menerapkan strategi yang efektif. Keberhasilan strategi juga bergantung kepada komitmen untuk melaksanakannya.

\section{Industri Kreatif}

Perkembangan zaman yang dimotori oleh teknologi dan globalisasi yang tidak dapat dicegah, membuat setiap negara untuk berlomba-lomba menjadi negara yang mampu bertahan dalam keadaan tersebut. Setiap negara berinovasi dan berimprovisasi untuk menciptakan suatu hal yang membuatnya dapat bersaing dengan negara lainnya. Industri kreatif muncul sebagai jawaban mengenai hal apa yang harus dilakukan negara dalam menghadapi persaingan dalam kancah internasional ini. Industri kreatif sendiri merupakan sebuah industri yang berfokus pada kreasi serta eksploitasi karya kepemilikan intelektual seperti seni, film, permainan atau desain fesyen, dan termasuk layanan kreatif antar perusahaan seperti iklan, dan lainnya (Togar M. Simatupang, Gatot Yudoko, Yuanita Handayati, dkk, 2018). Dari pengertian 
tersebut dapat disimpulkan bahwa yang dimaksudkan dengan industri kreatif merupakan sebuah industri yang bersumber dari sebuah ide pemikiran yang melalui proses berpikir kreatif seseorang. Industri kreatif, pada saat ini tidak terlepas dari perkembangan jaman serta teknologi yang ada. Dengan adanya perkembangan yang muncul, aktivitas-aktivitas ataupun kegiatan yang berpenghasilan dari proses tersebut dijadikan respon atas kemunculan perkembangan tersebut, termasuk perkembangan industri.

Menurut UNESCO industri kreatif adalah kegiatan produksi maupun pelayanan yang melingkupi elemen substansial dari segi artistik atau usaha untuk menciptakan dan mencakup aktivitas arsitektur dan periklanan. Sedangkan, industri kreatif merupakan akivitas yang memiliki keaslian dalam induvidu, bakat dan keterampilan serta memiliki potensi untuk menciptakan pekerjaan dan kesejahteraan melalui generasi dan eksploitasi hak kekayaan intelektual (Jones, 2006). Industri kreatif bukan hal baru di dunia internasional, terlebih sudah banyak negara yang menerapkan hal ini dan menjadi fokus serta kebijakan sebuah negara. Bukan hanya untuk mengembangkan kelompok masyarakat dengan sisi kreatif, akan tetapi pemberlakuan industri kreatif ini banyak menarik perhatian dari berbagai kalangan dan dapat meningkatkan pendapatan negara dari bidang yang berbeda.

Sebagai bidang baru yang muncul sebagai aksi terhadap perkembangan jaman, industri kreatif ini banyak dijadikan 
sebagai penyalur kreativitas seseorang yang sebelumnya tidak tahu bagaimana suatu hal yang tidak terlalu menarik justru bisa menjadi bidang yang menyumbangkan banyak terhadap negara. Menjadi satu dari empat gelombang ekonomi setelah ekonomi pertanian, ekonomi industri, dan ekonomi teknologi informasi dan komunikasi, ekonomi dalam bidang industri kreatif ini dijadikan sebagai pemanfaatan kreativitas dan keterampilan serta bakat individu untuk menciptakan kesejahteraan serta lapangan pekerjaan dengan menghasilkan dan mengekploitasi daya cipta tersebut (Agus Purnomo, 2018). Munculnya berbagai gelombang ekonomi tersebut didasarkan pada perkembangan teknologi serta aktor dalam hubungan internasional, di mana dengan segala kemungkinannya memunculkan berbagai hal baru bahkan yang tidak terbayangkan sebelumnya.

Ekonomi kreatif dianggap sebagai jenis ekonomi pertama yang menggunakan imajinasi dalam memutuskan apa yang dilakukan manusia dalam situasi tawar menawar yang terjadi dalam masyarakat (John Hawkins, 2018). Dalam bidang ekonomi ini orang-orang mencoba mengembangkan ide baru dari pekerjaan mereka. Dengan memunculkan harga tawar yang tinggi terhadap pembelian karya atau bentuk lain dari apresiasi yang dilakukan oleh pembeli. Kemunculan ekonomi kreatif ini diukur dengan adanya permintaan, harga, keuntungan dan margin seperti pada konsep ekonomi lainnya. Kemunculan ekonomi kreatif memberi dampak tersendiri bagi perkembangan ekonomi di mana hampir semua negara mulai 
untuk ikut perkembangan dengan melakukan berbagai strategi untuk dapat turut serta dalam perkembangan ekonomi dalam bidang kreatif ini. Setiap negara memiliki tujuan nasional yang berbeda, tetapi dengan pengadaan ekonomi kreatif ini semua negara berharap untuk dapat berinovasi dalam perkembangan zaman serta perkembangan ekonomi yang terjadi untuk menghadapi era integrasi pasar yang akan terjadi pada kemudian hari.

Saat ini, industri ekonomi kreatif merupakan salah satu hal yang tidak bisa dipisahkan dalam perkembangan ekonomi yang dijalankan oleh setiap negara. Oleh sebab itu, pemerintah pusat dari setiap negara mulai gencar memperkenalkan ekonomi kreatif khususnya kepada daerah untuk dijadikan sebagai pendapatan daerah yang nantinya dapat digunakan untuk pembangunan daerah yang turut serta mendukung aktivitas ekonomi kreatif. Terbilang rumit karena masih terdengar sebagai bidang yang asing karena baru diperkenalkan dan digiatkan untuk dikenalkan kepopulerannya, ekonomi kreatif memerlukan keikutsertaan berbagai pihak dalam pelaksanaannya. Seperti pemerintah pusat, pemerintah daerah, kebijakan yang saling berpadu antara pemerintah pusat dan daerah, masyarakat, dan kerjasama yang dijalankan dengan berbagai negara menjadi hal penting bagi berjalannya industri kreatif ini. 
Gambar III.1.

Gelombang Pergeseran Orientasi Ekonomi

Sektor Industri Kreatif

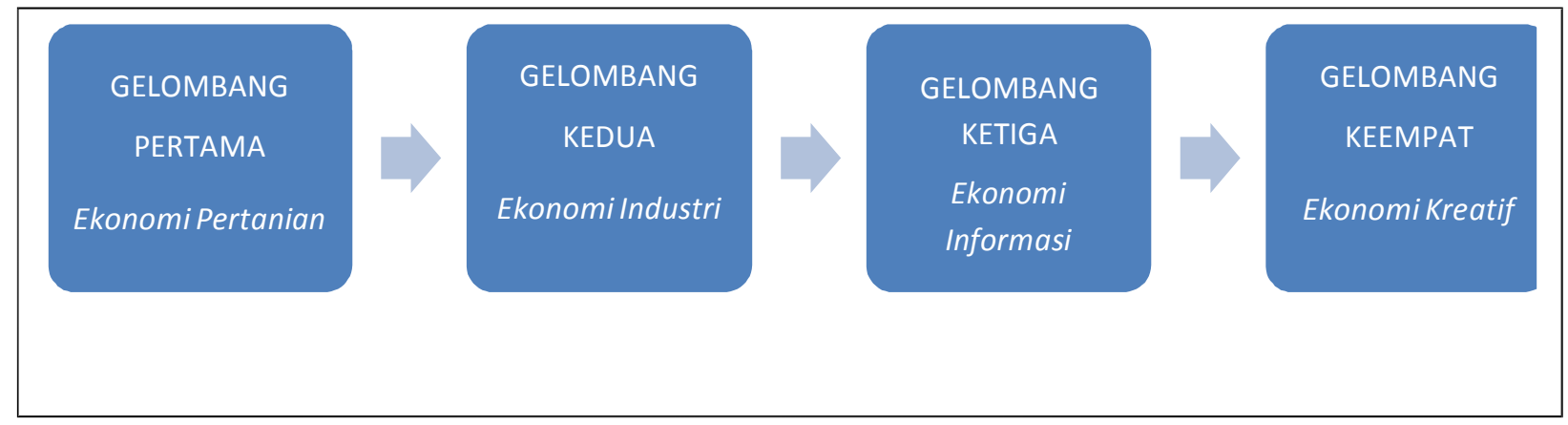

Sumber : Moelyono

(2010)

Tentunya tidak semua pekerjaan atau aktivitas dapat masuk ke dalam industri kreatif yang termasuk ekonomi kreatif. Beberapa ahli membagi dan menetapkan bahwa ada beberapa pekerjaan yang dapat masuk ke dalam sektor industri kreatif, dan ada juga yang tidak. Pembagian atau pengelompokan ini didasarkan pada kemampuan negara dalam mengatasi serta mengembangkan ekonomi kreatif dari negaranya tersendiri. Setiap bidang akan mendapatkan prosentase tersendiri sesuai peminatnya. Sebagaian dilihat dari berapa banyak orang yang bekerja pada bidang tersebut, dan yang lainnya dinilai dari berapa besar kontribusinya atau sumbangannya terhadap negara.

Adapun beberapa sektor yang termasuk ke dalam industri kreatif adalah segala usaha yang berhubungan dengan aktivitas kreatif dari seseorang. Dasarnya setiap negara memiliki fokus sendiri yang akan dijadikan sebagai ekonomi kreatif dari negaranya. Di Indonesia sendiri, 
pemerintah Indonesia dalam hal ini Departemen Perdagangan RI lebih dekat dengan klasifikasi yang digunakan oleh Howkins (2001) di mana sektor industri yang termasuk ke dalam bagian ekonomi kreatif antara lain adalah periklanan, arsitektur, pasar seni dan barang antik, kerajinan, desain, fesyen, video, film dan fotografi, permainan interaktif, musik, seni pertunjukan, penerbitan dan percetakan, layanan komputer dan piranti lunak, televisi dan radio, dan riset serta pengembangan (Togar M. Simatupang, 2018). Keempat belas bidang tersebut tentunya dapat dikategorikan sebagai ekonomi kreatif karena bidang-bidang ini dapat diterapkan di Indonesia, dan tentunya memberikan perkembangan yang pesat dalam pertumbuhan ekonomi yang ditandai dengan sumbangannya yang besar daripada sektor lainnya.

Setiap tahun ekonomi di Indonesia didominasi oleh sektor industri kreatif, dalam data statistik dan hasil survei ekonomi kreatif dalam kerjasama Badan Ekonomi Kreatif (BEKRAF) dan Badan Pusat Statistik (BPS) yang dirilis tahun 2017 disajikan bahwa 5 sektor yang sangat berpengaruh di Indonesia adalah kuliner (41,69\%) fesyen (18,15\%) kriya $(15,70 \%)$ televisi dan radio $(7,78 \%)$ dan penerbitan $(6,29 \%)$. Adapun sektor yang berkembang pertumbuhannya sangat pesat sejak tahun 2015 adalah desain komunikasi visual $(10,28 \%)$ musik (7,26\%) animasi video (6,68\%) serta arsitektur $(6,62 \%)$. Dengan data tersebut dapat dilihat bahwa ketertarikan masyarakat Indonesia terhadap industri kreatif semakin hari semakin meningkat. 
Gambar III.1.2 Subsektor Ekonomi Kreatif di Indonesia
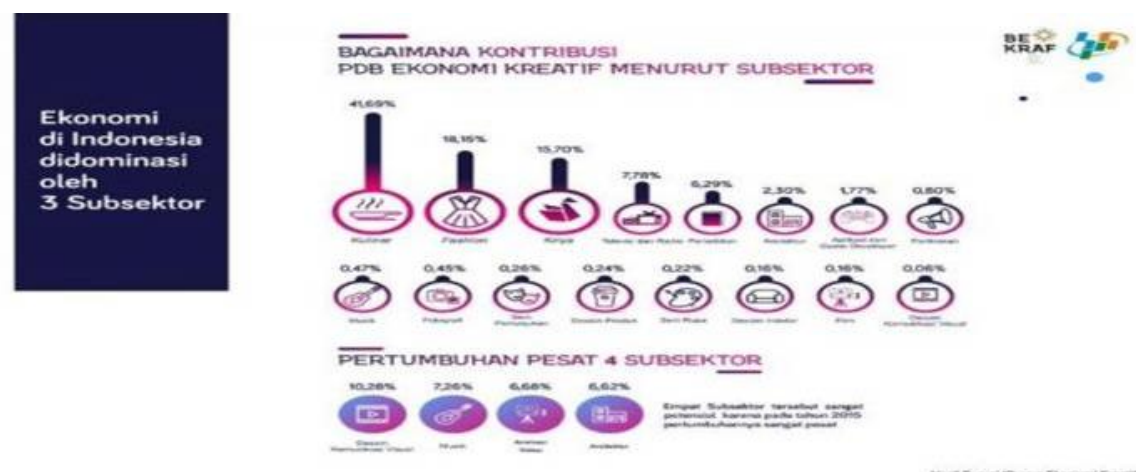

Dengan adanya pembagian sektor yang dijadikan sebagai standar atau alat ukur perkembangan industri kreatif di Indonesia ini, tentunya pemerintah memiliki tujuan pasti dalam menjalankan sektor yang telah disebutkan sebelumnya. Adanya sektor ini juga membuat setiap daerah dapat menetapkan fokusnya masing-masing dalam ikut serta menjalankan pembangunan sektor industri kreatif dalam menghadapi pasar bebas. Ini memungkinkan menjadikan kondisi Indonesia dapat bertahan dalam arus yang sulit ketika menghadapi persaingan bidang penjualan dengan negaranegara lainnya. Perkembangan sektor kreatif ini sangat terlihat di Jawa Barat. Hal ini dikarenakan Jawa Barat terkenal dengan pusat industri tekstil, dalam skala umum adalah pelaku usaha menengah. Hal ini juga menjadi alasan bahwa pemerintah Indonesia banyak memberikan perhatian kepada industri di Jawa Barat. Akan tetapi, walaupun begitu pemerintah pusat ikut serta dalam pembangunan industri di daerah lainnya. 


\section{Sejarah dan Perkembangan Industri Kreatif di Indonesia}

Muncul sebagai salah satu upaya untuk menjalankan perkembangan ekonomi di Indonesia. industri kreatif pada awalnya dianggap sebagai hal asing untuk dijalankan, hal ini tentu disebabkan Indonesia belum memakai industri kreatif sebagai motor ekonominya. Awal kemunculan industri kreatif di Indonesia adalah tahun 1998, di mana saat terjadinya krisis ekonomi Indonesia mencari berbagai cara untuk mengembalikan ekonominya. Maka indusri kreatif ini dianggap sebagai cara untuk mengembalikan kondisi menjadi lebih baik. Akan tetapi tidak semua sesuai dengan apa yang diharapkan, pelaksaan industri kreatif ini tidak sepenuhnya berjalan hal ini tentu disebabkan banyak hambatanhambatan yang membuatnya seolah hanya sebuah nama tanpa program yang berjalan. Hingga tahun 2005 presiden Indonesia saat itu Susilo Bambang Yudhoyono menyebutkan betapa pentingnya pengembangan ekonomi kreatif bagi masa depan Indonesia (Dhorifi Zumar, 2018).

Pada masa kepemimpinan Presiden Susilo Bambang Yudhoyono bahkan dikeluarkan kebijakan mengenai pengembangan ekonomi kreatif dalam Instruksi Presiden (Inpres) No.6 Tahun 2009. Dalam Inpres tersebut dijelaskan mengenai definisi dan berbagai kebijakan yang dibuat untuk pengembangan ekonomi kreatif di Indonesia. Meskipun begitu, sebenarnya industri kreatif telah berkembang jauh sebelum tahun 2000, tepatnya tahun 1998, di mana krisis global menjadi dasar alasan industri kreatif ini dikembangkan dan menjadi fokus di Indonesia. Jika dilihat dari hitungan tahun, 
memang Indonesia terlambat menyadari bahwa industri kreatif merupakan industri yang akan menguntungkan bagi Indonesia yang memiliki banyak budaya didalamnya. Negara-negara lain telah mengaplikasikan industri kreatif ini jauh lebih awal dari Indonesia, dan tentunya sudah menerima hasil dari perkembangan industri di bidang kreatif ini.

Di Indonesia, pelaksanaan industri kreatif sebagai sumber ekonomi ini dijadikan juga sebagai upaya pembangunan ekonomi nasional. Ekonomi kreatif di Indonesia dijadikan sebagai upaya pembangunan ekonomi secara berkelanjutan melalui kreativitas dengan iklim perekonomian yang berdaya saing dan memiliki cadangan sumber daya terbarukan (Departemen Perdagangan Republik Indonesia, 2018). Pelaksanaannya di Indonesia pada awalnya tidak berjalan sebaik hari ini. Hal tersebut disebabkan terlalu dini untuk menilai keberhasilan suatu rancangan di awal. Maka Indonesia meningkatkan industri kreatifnya secara terus menerus. Pada tahun 2006 Departemen Perdagangan mengeluarkan data di mana industri kreatif telah menghasilkan sebesar Rp. 104,4 triliun, atau rata-ratanya 4,74\% terhadap PDB nasional selama tahun 2002-2006. Tentu jumlah ini bukan jumlah yang sedikit, bahkan jika dibandingkan dengan penghasilan dari sektor lainnya industri kreatif ini menjadi salah satu penyumbang penghasilan terbesar. Akan tetapi, jumlah tersebut masih dikatakan sedikit jika harus dibandingkan dengan penghasilan negara-negara lainnya dari industri kreatif. Namun, dengan data tersebut pemerintah dapat melihat bahwa dengan adanya industri 
kreatif ini sangat membutuhkan dukungan dari berbagai pihak. Tentu dengan adanya berbagai elemen yang turut ikut serta dalam pembangunan khususnya ekonomi kreatif ini, tujuan dari penerapan ekonomi kreatif di Indonesia ini akan mudah tercapai.

Perkembangan pesat industri kreatif terjadi pada tahun 2015. Berdasarkan data yang dirilis oleh Badan Ekonomi Kreatif (Bekraf) dan Badan Pusat Statistik (BPS), bidang ekonomi kreatif berhasil menyumbangkan sekitar 8252 triliun rupiah atau meningkat sekitar 7,38 persen terhadap total PDB Indonesia dibandingkan pada tahun sebelumnya. Hasil ini menunjukan adanya peningkatan yang terjadi dalam bidang ekonomi kreatif. Jumlah ini menjadi salah satu alasan bagi pemerintah untuk terus berkoordinasi dengan pemerintah daerah dengan tujuan untuk meningkatkan industri kreatif. Bahkan pada tahun 2016 menurut data yang sama, Indonesia berhasil mencatatkan pertumbuhan ekonomi nasional sebesar 5,02 persen. Jumlah ini menjadi nilai tertinggi setelah penghasilan dari bidang yang sama, yaitu dengan negara India dan Tiongkok di antara negara-negara G20 (Badan Ekonomi Kreatif, 2018).

Pengembangan industri kreatif ini dianggap sebagai suatu hal yang bagus bagi setiap daerah, pasalnya setiap daerah di Indonesia pada dasarnya memiliki keanekaragaman seni, budaya, serta wisata yang melimpah. Dapat dibayangkan jika setiap daerah mulai turut berfokus pada pengembangan industri kreatif, akan berapa banyak yang diterima negara sebagai hasil dari kepentingan nasional Indonesia dalam 
bidang kreatif. Dengan alasan itulah Indonesia mulai berbondong-bondong untuk mengembangkan industri ini dalam bidang yang berbeda-beda, dan diikuti oleh negara lainnya. Perkembangan industri kreatif ini didasarkan karena adanya berbagai bidang atau sektor yang termasuk dalam ekonomi kreatif yang berkontribusi besar dalam pembangunan ekonomi Indonesia. Munculnya industri ekonomi kreatif ini juga dianggap sebagai cara untuk menciptakan iklim bisnis yang positif, membangun citra bangsa, serta memberikan dampak sosial yang positif dalam masyarakat (Departemen Perdagangan Republik Indonesia. 2018).

Adanya konsep indsutri dan ekonomi kreatif ini meluas menjadi dimunculkannya kota kreatif sebagai jawaban dari langkah apa saja yang dilakukan oleh sebuah negara untuk menjalankan aspek-aspek industri kreatif untuk mencapai tujuan dari ekonomi kreatif. Gagasan mengenai kota kreatif pertama kali disebutkan tahun 1991 oleh Charles Landry dalam bukunya yang berjudul The Creative and Its Cultural Economy. Kota kreatif dijadikan sebagai cara mengatasi masalah-masalah yang muncul dalam perkembangan jaman seperti masalah urbanisasi, kemacetan, masalah sosial ekonomi dan masalah-masalah lainnya yang tercipta sebagai sebab dan akibat masuknya globalisasi ke Indonesia sebagai fenomena yang tidak dapat dihindari. Kota kreatif diterapkan pertama kali oleh negara Inggris, tentu pelaksanaan kota kreatif ini memacu negara-negara lainnya untuk melakukan hal serupa, bahkan penerapan kota kreatif ini dilakukan juga oleh Amerika dan Eropa saat masuk tahun 2000-an. 
Keseriusan Indonesia dalam ikut serta dalam pembangunan ekonomi dalam bidang ekonomi kreatif ditandai dengan adanya peraturan mengenai ekonomi kreatif di Indonesia dimulai sejak adanya Peraturan Presiden (Perpres) Nomor 72 Tahun 2015 tentang perubahan Perpres No.6 Tahun 2009 mengenai Badan Ekonomi Kreatif (Bekraf). Tidak berbeda dengan negara lainnya, di Indonesia juga kota kreatif dijadikan sebagai salah satu upaya yang dilakukan oleh BEKRAF dalam menjalankan fungsi serta tugas untuk merumuskan berbagai hal yang berhubungan dengan industri kreatif, khususnya ekonomi kreatif. Satu dari kegiatan yang dilakukan BEKRAF adalah penilaian mandiri ekonomi kreatif sebuah daerah. Penilaian mandiri daerah ini diharapkan dapat menghasilkan database ekonomi kreatif di Indonesia, mengidentifikasi subsektor potensial, juga mengetahui kendala apa saja yang dihadapi oleh daerah dalam menerapkan ekonomi kreatifnya (Badan Ekonomi Kreatif, 2016).

Konsep penilaian mandiri yang dikeluarkan oleh pemerintah merupakan jawaban di mana harus ada kebijakan yang membuat kota-kota di Indonesia ikut serta dalam pembangunan ekonomi yang dilakukan oleh Indonesia. Dengan penerapan ini bukan hanya pemerintah pusat yang mendapatkan manfaat. Bagi pemerintah dengan dijalankannya penilaian mandiri ini, tentu akan membawa Indonesia mewujudkan "Sistem Ekonomi Kreatif Nasional" sebagai pembangunan ekonomi. Tentunya program ini akan memudahkan pemerintah kota untuk membangun serta 
mengembangkan ekonomi kreatifnya. Dengan melihat setiap potensi yang dimiliki setiap daerah akan pemerintah dapat melakukan pemetaan, kota mana saja yang harus dikembangkan potensi kreativitasnya dan kota mana yang harus memulai mengembangkan ekonomi kreatif. Cara ini akan membantu perkembangan ekonomi kreatif di Indonesia.

Badan Ekonomi Kreatif (BEKRAF)

Merupakan lembaga baru non-kementerian yang bertanggung jawab terhadap perkembangan ekonomi kreatif Indonesia. BEKRAF disahkan melalui Peraturan Presiden Republik Indonesia Nomor 6 Tahun 2015 Tentang Badan Ekonomi Kreatif, pada 20 Januari 2015. BEKRAF memiliki tugas membantu presiden dalam merumuskan, menetapkan, mengkoordinasikan, dan sinkronisasi kebijakan di bidang ekonomi kreatif. Hal ini dilakukan atas pertimbangan adanya peningkatan Produk Domestik Bruto (PDP) setiap tahunnya dalam bidang industri kreatif, dengan fakta ini pemerintah mencoba mengkokohkan fondasi perekonomian di mana ekonomi kreatif bertumpu pada keunggulan sumber daya manusia (SDM).

BEKRAF mempunyai visi membangun Indonesia menjadi salah satu kekuatan ekonomi dunia dalam ekonomi kreatif pada 2030 nanti. Untuk mencapai visi tersebut, BEKRAF merancang enam misi besar, yaitu:

1. Menyatukan seluruh aset dan potensi kreatif 
Indonesia untuk mencapai ekonomi kreatif yang mandiri.

2. Menciptakan iklim yang kondusif bagi pengembangan industri kreatif.

3. Mendorong inovasi di bidang kreatif yang memiliki nilai tambah dan daya saing di dunia internasional.

4. Membuka wawasan dan apresiasi masyarakat terhadap segala aspek yang berhubungan dengan ekonomi kreatif.

5. Membangun kesadaran dan apresiasi terhadap hak kekayaan intelektual, termasuk perlindungan hukum terhadap hak cipta.

6. Merancang dan melaksanakan strategi yang spesifik untuk menempatkan Indonesia dalam peta ekonomi kreatif dunia.

Dengan menjalankan tugas dan fungsi-fungsi tersebut, BEKRAF optimis bisa menciptakan ekosistem ekonomi kreatif yang efisien dan kondusif. Dengan begitu, para pelaku bisa berkarya lebih baik sehingga ekonomi kreatif bisa memberikan kontribusi pendapatan yang selalu meningkat terhadap PDB nasional.

Keseriusan BEKRAF dalam menjalankan fungsi dan tugasnya mulai terlihat pada tahun 2018 , di mana pada tahun 
ini banyak kegiatan-kegiatan dari BEKRAF yang terlihat sangat mendukung industri kreatif yang masuk ke dalam fokus aspek/bidang yang sedang berusaha dijalankan oleh Indonesia. Hal ini menjadi peluang sekaligus kesempatan yang bagus bagi Indonesia di mana dengan memiliki badan yang fokus terhadap bidang yang baru ini, maka akan menciptakan keseimbangan terhadap pasar Indonesia. Hal ini tentu juga membuka kesempatan bagi orang-orang yang berfokus pada ekonomi kreatif sebagai usahanya. Bahkan, bukan hanya melaksanakan kegiatan-kegitan yang mendukung ekonomi kreatif saja, bahkan BEKRAF melaksanakan workshop bersertifikat bagi para kreatif yang ini memfokuskan keahliannya dan membuat usaha dari bidang yang digelutinya.

Berbagai bidang pun masuk ke dalam fokus BEKRAF. Dimulai dari kepenulisan, desain, bahkan barista. Dilihat dari kegiatan yang dilaksanakan oleh BEKRAF tentu akan tergambarkan bagaimana badan khusus ekonomi kreatif ini sudah mulai menjalankan tujuannya, walaupun masih perlahan untuk mewujudkan Indonesia yang kreatif.

\section{Sejarah dan Perkembangan Industri Kreatif di Kota Bandung}

Kota Bandung merupakan ibu kota Jawa Barat yang memiliki peran besar dalam menjalankan ekonomi kreatif Indonesia. Memiliki kapasitas sebagai pusat distribusi (Point of Distribution) dalam bidang ekonomi khusunya ekonomi kreatif bagi wilayah lainnya, kota ini dipercaya dapat 
menciptakan ruang kreatif bagi masyarakat Indonesia. Pemilihan Kota Bandung sebagai kota percontohan kreatif bagi wilayah lainnya dikarenakan berbagai faktor yang dimiliki oleh Kota Bandung, yaitu: (1) Masyarakat yang berkreatifitas tinggi, tentu hal ini tidak terlepas dari banyaknya komunitas anak muda yang bergerak dalam berbagai bidang kreatif. Berbagai komunitas yang muncul sebagai asal-usul ekonomi kreatif di Bandung ini juga didukung dengan latar belakang Jawa Barat khususnya Kota Bandung yang memiliki aneka ragam seni dari musik, hingga kebudayaan yang mendorong perilaku kreatif masyarakatnya. (2) Fasilitas yang terus berkembang. Menyadari tingkah laku masyarakatnya yang kreatif, pemerintah Kota Bandung turut membangun berbagai fasilitas untuk itu serta dalam menggalakan kreativitas masyarakatnya. Berbagai fasilitas yang adapun dijadikan sebagai tempat yang tepat untuk melakukan berbagai kegiatan yang menyebabkan pemerintah Kota Bandung ikut mendukung kegiatan-kegiatan dari berbagai komunitas.

Industri ekonomi kreatif ini berkembang dan terus mengalami peningkatan di Kota Bandung. Terlebih dalam kurun 10 tahun terakhir, Kota Bandung menyumbang pemasukan atau Domestik Regional Bruto (DRB) yang sangat bedar terhadap negara. Dari nilainya perputaran uang dari sector industri kreatif ini bahkan mencapai Rp.79 miliar/Bulan. Walaupun begitu industri ini belum bekerja dengan maksimal di berbagai sisinya. Ini yang menyebabkan masih harus banyak yang diperbaiki, dari sisi kebijakan yang dibuat oleh pemerintah Kota Bandung ataupun dari 
masyarakat sebagai pelaku kreatif yang terdapat di Kota Bandung. Bukan hanya mengenai DRB saja yang meningkat pada kurun 10 tahun terkhir. Akan tetapi, Kota Bandung juga dijadikan sebagai kota percontohan dalam bidang ekonomi kreatif. Fakta ini dikeluarkan sejalan dengan adanya perkembangan yang signifikan dan memengaruhi tren anak muda di berbagai kota mengenai pemahaman industri kreatif.

Bersamaan dengan berbagai perkembangan yang terjadi di Kota Bandung terlebih mengenai industri dan ekonomi kreatif, akhirnya kota ini mendapatkan pengakuan dari berbagai negara. Salah satunya masuk ke dalam 5 kota kreatif se-Asia dalam survei media Singapura, Channel News Asia pada Desember tahun 2011. Usahanya tidak sia-sia ketika pada tahun 2015 Kota Bandung terpilih menjadi Kota Kreatif dalam kategori desain oleh UNESCO. Pengakuan yang diberikan oleh UNESCO membuat Pemerintah Kota Bandung memulai kembali inovasi terbarunya mengenai industri kreatif. Salah satunya dibentuknya Bandung Creative Community Forum, di mana BCCF ini digunakan sebagai penghubung antara pembuat keputusan dengan komunitas-komunitas kreatif yang ada di Bandung. Dengan adanya hal ini diharapkan kerjasama yang dilakukan oleh pemerintah Kota Bandung dengan masyarakat bekerja dan menghasilkan berbagai produk kreatif lainnya untuk memperkenalkan industri kreatif Kota Bandung.

Berbagai upaya dijalankan oleh pemerintah Kota Bandung untuk terus meningkatkan industri kreatifnya, yaitu: (Tuty Herawati, 2014). 
1. Memfasilitasi terselenggaranya Helar Fest yang merupakan salah satu program yang dikembangkan oleh BCCF sebagai bagian dari strategi jangka panjang pengembangan platform ekonomi kreatif yang berkelanjutan di Kota Bandung.

2. Mengamanatkan pelaksanaan pembangunan ekonomi kreatif dalam dokumen perencanaan RPJP, RPJM dan RKPD Kota Bandung.

3. Melakukan kajian dalam rangka persiapan penyusunan kebijakan, baik yang dilakukan melalui kerjasama dengan pihak ketiga (jasa konsultasi) maupun melalui Forum Pemasaran Kota dan Dewan Pengembangan Ekonomi (DPE) Kota Bandung.

4. Kajian City Branding dan perencanaan landmark Kota Bandung yang dilakukan melalui Komisi Forum Pemasaran Kota.

5. Kajian Investasi Bidang Pengembangan Industr Kreatif yang dilakukan melalui Kelompok Kerja DPE Kota Bandung.

6. Pembangunan Taman Kreatif Kota (di bawah jembatan Pasupati).

7. Pembangunan monumen Taman Cikapayang (Huruf DAGO raksasa). 
8. Fasilitasi dalam bidang promosi dan pemasaran melalui Dekranasda Kota Bandung, diantaranya pelaksanaan Pameran Kriya Pesona Bandung (KPB).

9. Menyusun Konsep Penciri Kota pada gerbang masuk kota Bandung.

10. Menurut Wakil Gubernur Dede Yusuf, Pemprov Jabar telah menyediakan lahan seluas 10 hektar di wilayah Pasir Kunci, Ujung Berung, untuk menampung kreatifitas seniman Bandung dan meningkatkan industri kreatif di wilayah ini.

Kota Bandung dikenal dengan kota yang memiliki banyak potensi dalam bidang industri kreatifnya, hal inilah yang menyebabkan kota ini dipilih sebagai Kota Kreatif versi berbagai macam instansi dan media. Pemberian sandangan Kota Kreatif ini bukan tanpa perhitungan, banyaknya komunitas menjadi salah satu hal yang membuat Kota Bandung dianggap sebagai kota yang dapat mengembangkan berbagai hal mengenai industri kreatif. Salah satu perkembangan yang tidak dapat dipungkiri adalah perkembangan jumlah outlet pertokoan yang kota ini miliki, dalam kurun sepuluh tahun kota ini mengalami peningkatan bahkan hingga 2 kali lipat dari jumlah 200 unit menjadi 400 unit yang dimiliki Kota Bandung pada tahun 2014-an, dan 
bahkan terus bertambah setiap tahunnya. Hal ini tentu menjadi kebanggaan di mana dapat memotivasi aktor yang memiliki peran dalam industri kreatif untuk terus berinovasi dan mampu bersaing dengan pasar, khususnya pasar luar negeri.

Dari 14 sektor yang masuk kedalam sektor industri kreatif Indonesia, terdapat 6 sektor yang menjadi sektor unggulan Kota Bandung, yaitu: (Tuty Herawati, Chistina L Rudatin, dan Djuni Akbar, 2014).

\section{Industri Fashion}

Kota Bandung dikenal dengan pasar mode, di mana kota ini memiliki banyak tempat perbelanjaan khususnya mengenai pakaian. Hal ini juga yang menyebabkan kota ini dikenal juga dengan sebutan Paris Van Java atau Kota Parisnya Jawa, kaitan ini tentu tidak dapat dilepaskan dari Paris yang sangat dikenal sebagai kota fashion dan desainer. Iklim tersebutlah yang menyebabkan para kreatif di bidang fashion turut serta dalam mengambil kesempatan yang besar dengan memilih bisnis Factory Outlet, Clothing Company, dan Distribution Store.

\section{Industri Desain}

Keunggulan Kota Bandung dalam industri desain ini bahkan menyebabkan UNESCO pada tahun 2015 memilih Kota Bandung sebagai Kota Desain. Kesempatan tersebut tentu dijadikan sebagai upaya bagi Kota bandung untuk terus mengembangkan industri ini, khususya dalam industri desain. Jauh sebelum dipilih sebagai Kota Desain oleh UNESCO, 
industri ini sudah sangat berkembang di Bandung. Hal ini dikarenakan banyaknya produsen yang memulai bisnisnya dalam bidang kreatif ini. Kreatifitas yang dihargai oleh para konsumen ini bahkan menjadikan industri ini terus dikembangkan sebagai salah satu bidang kreatif unggulan di Kota Bandung.

\section{Industri Informasi dan Teknologi}

Kemajuan teknologi disinyalir akan membawa dampak yang sangat besar bagi perkembangan sebuah negara. Hal ini pulalah yang menyebabkan negara terus berusaha memperbaiki sistem infomasi dan teknologinya. Kota Bandung menjadi salah satu kota yang juga berfokus pada pengembangan teknologi. Di mana pemerintah bersinergi dengan masyarakat untuk terus berfokus memperaiki kekurangannya, hal tersebut menjadi landasan adanya kerjasama yang dilakukan oleh masyarakat dengan swasta untuk mengembangkan sektor industri informasi dan teknologi.

\section{Industri Kuliner}

Indonesia dikenal sebagai negara dengan beragam suku dan budaya, potensi inilah yang menyebabkan industri kuliner memiliki kesempatan besar untuk terus berkembang. Kota Bandung memanfaatkan potensi tersebut untuk memperkenalkan potensi budaya khususnya bidang kuliner. Pelaku usaha memafaatkan kesempatan ini dengan turut membuka bisnis kuliner dengan menu masakan nusantara. 


\section{Industri Seni dan Kerajinan}

Terlihat dari iklim seni yang dimiliki oleh Kota Bandung tentu jelas terlihat bahwa kota ini sangat memerhatikan berbagai hal yang berkaitan dengan seni dan kerajinan. Hal ini jelas tergambar dimana terdapat jalan yang menjajakan hasil kriya dan diperjualbelikan. Adanya minat masyarakat untuk sekadar melihat atau bahkan membeli, menambah kesempatan bagi industri ini terus berkembang dan diterima oleh masyarakat.

\section{Industri Pertunjukan/Showbiz}

Sektor pertunjukan juga dijadikan sebagai sektor unggulan, di mana Kota Bandung melakukan banyak kegiatan yang salah satunya adalah pertunjukan. Ini terlihat dari antusiasme para wisatawan yang datang untuk berkunjung ke Kota Bandung dan menyempatkan untuk datang menonton berbagai event musik seperti salah satunya pertunjukan di Saung Angklung Udjo.

Berbagai kebijakan pun dibuat oleh Pemerintah Kota Bandung demi menciptakan iklim kreatif pada masyarakat Bandung. Akan tetapi, tidak semua berjalan dengan baik bahkan beberapa kebijakan terhambat oleh berbagai masalah yang muncul di masyarakat. Minimnya fasilitas masih menjadi masalah di Kota Bandung yang dikatakan sebagai kota kreatif Indonesia. Jika dihitung memang Kota Bandung memiliki berbagai bangunan atau taman yang mencerminkan 
kreativitas masyarakat Bandung, tetapi jika harus dibandingkan dengan negara-negara lain yang juga masuk dalam kategori kota kreatif oleh UNESCO, Kota Bandung masih berada jauh dengan negara-negara atau kota kreatif lainnya. Hal ini yang memunculkan pertanyaan mengenai hal apa lagi yang harus dilakukan pemerintah Kota Bandung beserta masyarakatnya untuk menjadi kota kreatif sesuai dengan kota di negara lain. Meskipun tidak ada standar tertentu mengenai kota kreatif, tetapi masih banyak hal yang harus dikembangkan oleh Pemerintah Kota Bandung dalam upaya pembangunan sebagai kota kreatif Indonesia

Hal lain yang menjadi masalah bagi masyarakat dalam turut serta membangun industri kreatif kota Bandung adalah sulitnya akses masyarakat terhadap modal perbankan. Tentu kondisi ini mengahambat masyrakat yang telah ada atau baru memulai usaha di industri kreatif. Dalam hal ini tentu sangat berkaitan erat dengan peran pemerintah yang seharusnya ikut memberikan stimulus terhadap masyarakat yang ingin ikut dalam pembangunan industri kreatif yang selama ini banyak dibangun oleh pemerintah. Birokrasi yang sulit masih sering kali menghambat berbagai hal terkait perizinan di Indonesia, dan hal serupa pun terjadi di kota Bandung. Tentunya dengan berbagai kesempatan untuk permbagunan ekonomi seharusnya permerintah memberi berbagai kemudahan terhadap masyarakat. 


\section{Sejarah dan Latar Belakang ASEAN Free Trade Area}

Kemunculan perkembangan zaman dan globalisasi secara tidak langsung memaksa negara-negara di seluruh dunia untuk saling bekerja sama. Bukan hanya itu kerjasama yang dibuat oleh negara memiliki tujuan lain yang dimaksudkan untuk menyampaikan pesan saling menguntungkan antara negara yang bekerja sama. Tidak terlepas dari kepentingan nasional setiap negaranya, kerjasama yang terjalin antara berbagai negara dilandaskan atas kebutuhan negara terhadap suatu hal yang dibutuhkan oleh masyarakat negaranya yang saling menguntungkan. Munculnya organisasi secara umum ditujukan untuk menghilangkan jarak antara hambatan yang dilalui oleh negara dengan pencapaian mudah yang dilakukan bersama dengan negara lain. Pergantian dari abad 20 menuju abad 21 memunculkan berbagai peristiwa, di mana salah satunya adalah lahirnya ekonomi politik internasional (Umar Suryadi Bakry, 2000). Hadirnya era Ekonomi Politik Internasional (EPI) ini membuat negara-negara yang memiliki tujuan atau kepentingannya sendiri, tidak dapat menghindar, menolak, atau mengisolasi diri dari perkembangan yang terjadi dalam ekonomi dunia.

ASEAN Free Ttrade Area (AFTA) menjadi penanda bahwa perkembangan era yang terjadi di dunia, terutama mengenai perkembangan ekonomi dunia merupakan hal yang nyata. AFTA merupakan sebuah kesepakatan dalam bidang ekonomi yang dibuat oleh negara-negara anggota ASEAN, di mana dengan hadirnya AFTA negara-negara anggotanya memiliki tujuan untuk menciptakan pasar tunggal bebas, bahkan 
tujuan akhir yang akan dicapai oleh AFTA adalah adanya Custom Union, yaitu penghapusan hambatan perdagangan dan mempersiapkan menghadapi globalisasi ekonomi merupakan hal penting yang menjadi agenda besar AFTA. Dibentuk pada KTT ASEAN ke IV di Singapura tahun 1992 yang berlandaskan ASEAN Vision 2020, diberlakukannya AFTA dilandasi beberapa faktor yaitu: (1) Munculnya berbagai konflik menyebabkan ASEAN membutuhkan sebuah badan atau organisasi yang dapat mempertahankan ASEAN sebagai organisasi regional, hal ini dijadikan negara-negara ASEAN untuk mendiskusikan bidang kajian dari ASEAN, yaitu bidang ekonomi. (2) Adanya negara-negara yang hanya mengandalkan perdagangan sebagai sumber kehidupan seperti negara Singapura, hal ini membuat banyaknya dukungan yang sangat berpengaruh pada perkembangan ASEAN. (3) Adanya keinginan dari negara ASEAN untuk mendatangkan sebanyak mungkin investor asing dari berbagai negara. (4) Tumbuhnya berbagai blok ekonomi yang membuat ASEAN seolah terpacu untuk melakukan hal yang serupa (Bambang Cipto, 2000).

Keberadaan AFTA ini juga dijadikan sebagai acuan untuk menjadikan ASEAN sebagai pasar komoditas yang mampu bersaing secara global, dengan salah satu tujuannya adalah menciptakan pasar regional bagi 500 juta penduduknya, serta membentuk integrasi antara negaranegara yang menandatangani KTT VI ASEAN (Ratna Shofi Inayati, 2016). Berbagai tujuan yang ingin dicapai tidak terlepas dari rasa bersaing antar negara yang menganggap sektor ekonomi sebagai sektor penting yang dapat memajukan 
negaranya. Tentunya dengan penguasaan ekonomi, negara akan mudah untuk menjalankan kepentingan nasional dengan negara lain. Demi tercapainya tujuan dari AFTA ini, berbagai hal dilakukan dimulai dari menghapus pajak impor dan ekspor, penurunan tarif, penghapusan hambatan non-tarif, bahkan dengan adanya Common Effective Preferential Tariff yang memiliki berbagai program didalamnya menjadi wujud nyata dari keseriusan negara-negara yang tergabung dalam AFTA dalam mencapai tujuan yang diinginkan.

AFTA sebagai bentuk kerjasama yang digunakan anggota negara ASEAN banyak membuat peraturan-peraturan yang berhubungan erat dengan ekonomi dan tujuan akhir dari AFTA sendiri. Pada KTT Informal ke-1 tahun 1997, AFTA memperkenalkan Visi ASEAN 2020, di mana tujuannya adalah mewujudkan masyarakat ASEAN (ASEAN Community). Dengan dibentuknya masyarakat ASEAN, menandakan bahwa negaranegara yang terbentuk dalam ASEAN mulai menetapkan fokusnya menjadi beberapa hal. Ada tiga pilar masyarakat ASEAN yang menjadi salah satu dasar adanya keseriusan negara anggota terhadap berbagai hal yang akan diutamakan dalam kerjasama negara-negara anggotanya. Tiga pilar dalam masyarakat ASEAN adalah Masyarakat Politik- Keamanan ASEAN (ASEAN Political-Security Community-APSC), Masyarakat Ekonomi ASEAN (ASEAN Economic Community$A E C$ ) dan Masyarakat Sosial-Budaya ASEAN (ASEAN SocioCultural Community-ASCC). Dengan adanya Masyarakat Ekonomi ASEAN dapat terlihat jelas bahwa negara-negara ASEAN memang memiliki fokus untuk mengedepankan 
perdagangan sebagai salah satu tujuan yang harus dicapai.

Agenda kelanjutan dari adanya Masyarakat Ekonomi ASEAN yang menjadi salah satu dari tiga pilar ASEAN adalah pertemuan Menteri Ekonomi ASEAN (ASEAN Economic Ministers Meeting) yang ke-38 di Cebu, Filipina tahun 2007 menghasilkan kesepakatan "Declaration on the Acceleration of the Establishment of an ASEAN Community by 2015". Dengan kesepakatan yang dihasilkan pada pertemuan tersebut tentu membuat negara anggota lainnya harus segera mempersiapkan diri untuk menghadapi pasar bebas yang sudah menjadi kesepakatan bersama. Pada dasarnya jika dilihat dari pandangan bagaimana tingkatan negara anggota, khususnya dalam bidang ekonomi, tentu tidak semua negara siap dengan keadaan yang mengharuskan membuka pasar bagi barang-barang impor dari negara lain. Hal ini disebabkan masih ada industri dalam negeri sendiri yang harus mendapatkan lebih banyak perhatian, seperti infant industries dan UMKM.

Ada beberapa hal yang menjadikan AFTA ini diberlakukan di ASEAN. Pertama, dijadikannya ASEAN sebagai organisasi ekonomi kawasan tidak menyalahi aturan global dalam GATT/WTO. Kemunculan AFTA ini bahkan dianggap sebagai salah satu upaya yang mendukung berjalannya berbagai kebijakan GATT yang ada. Maka keberadaan AFTA juga dapat dikatakan penting bagi berbagai pihak (Ratna Shofi Inayati, 2016). Kedua, adanya kebutuhan terhadap ekonomi yang dihadapi oleh negara-negara di ASEAN menjadikan dorongan bahwa organisasi regional bidang ekonomi 
diperlukan. Meskipun tidak mudah dijalankan akan tetapi kesepakatan ini merupakan sebuah langkah bersama yang dijalankan oleh anggota menuju tujuan yang sama.

\section{ASEAN Economic Community}

AEC dijadikan sebagai wujud nyata mengenai keseriusan negara anggota dalam kesiapannya menghadapi pasar bebas ekonomi. yang digagas sebagai bentuk tahap selanjutnya dari kerjasama yang terjadi di kawasan ASEAN. Menjadi salah satu dari pilar utama dari ASEAN yang pada awalnya direncanakan akan tercapai tahun 2020. AEC diharapkan dapat menjadi dasar bagi perdagangan barang, jasa, investasi, teknologi, dan sumber daya antar negara ASEAN pada kemudian hari (Bambang Cipto, 2000). Juga menjadi bentuk integrasi regional yang kompetitif bagi kegiatan investasi dan perdagangan bebas yang dapat memberikan manfaat bagi seluruh negara ASEAN. Selain itu dibentuknya AEC ini menjadi cara untuk membantu negara-negara ASEAN yang cenderung masih harus membangun ekonominya dengan masalah kemiskinan dan mencapai kesejahteraan di masyarakatnya. Kerjasama ekonomi negara-negara anggota diharapkan dapat membantu pembangunan bidang ekonomi di sebuah negara, dengan harapan tercapainya visi dan misi dari ASEAN.

Pelaksanaan AEC ini tidak bisa terlepas dari segi hukum yang akan membantu berjalannya setiap kebijakan yang dibuat oleh AEC. Secara segi hukum, Piagam ASEAN tahun 2008 menjadikan kesepakatan ASEAN yang sebelumnya 
merupakan organisasi yang longgar (Loose Association) menjadi sebuah organisasi yang berlandaskan hukum (Rulebased Organization) atau menjadi organisasi yang kesepakatannya mengikat para anggotanya. AEC memiliki hukum yang kuat dan mengikat (Legally Binding), serta memiliki prinsip "Pacta Sund Servanda" yang menyatakan bahwa setiap anggota ASEAN harus ikut mengimplementasikan AEC dengan segala konsekuensi yang ada didalamnya, hal ini tertera dalam Pasal 47 Piagam ASEAN dan Cetak Biru AEC (Delfiyanti, 2015). Dengan adanya hukum yang mengikat, maka negara-negara anggota yang telah menyetujui perjanjian harus bersedia untuk mengikuti berbagai kententuan yang diberikan oleh kesepakatan AEC. Hal ini tentunya menjadi pengingat bahwa setiap negara akan ikut serta untuk membangun negaranegara ASEAN secara bersama-sama baik dalam bidang apapun, khususnya bidang ekonomi.

AEC memiliki empat karakteristik utama yang juga dijadikan sebagai tujuan dasar dalam pelaksanaannya, yaitu: (1) Pasar tunggal dan basis produksi atau single market and production base. (2) Kawasan yang memiliki daya saing tinggi atau higly competitive region. (3) Kawasan dengan pembangunan ekonomi yang merata atau region of equitable economic development. (4) Integrasi perekonomian kawasan dengan perekonomian global atau integration into the global economy (ASEAN Economic Community Blueprint). Keempat karakteristik ini tertuang dalam cetak biru AEC yang dijadikan sebagai acuan untuk mencapai tujuan yang ingin dicapai. 
Tidak hanya itu dalam cetak biru yang dihasilkan dalam pertemuan ke-38 ASEAN Economic Ministers di Kuala Lumpur, Malaysia pada tahun 2006 tersebut terdapat berbagai kebijakan yang dibuat untuk mendukung terlaksananya AEC agar tercapai sesuai dengan tujuan awalnya.

Berbagai bentuk kerjasamapun dilakukan oleh negaranegara anggota AEC. Salah satunya kerjasama bidang barang, perdagangan barang, juga kerjasama bidang jasa. Dalam sektor industri kerjasama yang dilakukan dengan tujuan untuk meningkatkan investasi asing yang masuk ke dalam negeri, peningkatan teknologi, sembangunan kapasitas negara anggota, serta pertukaran informasi perencanaan industri. Hingga dibentuknya ASEAN Industrial Cooperation yang digunakan sebagai usaha untuk meningkatkan daya saing perusahaan di negara ASEAN. Selanjutnya bidang perdagangan barang, tentu setelah peningkatan kualitas dari barang maka tingkat selanjutnya adalah membicarakan serta merencanakan berbagai hal mengenai penyebaran barang tersebut dengan perdagangan. Mengenai hal ini dibentuk kesepakatan ASEAN Trade in Goods Agreement pada tahun 2010. Dengan adanya ATGA ini diharapkan akan terbentuknaya integrasi inisiatif ASEAN yang berkaitan dengan perdagangan barang ke dalam negeri. Bidang yang juga tidak kalah penting yang dijadikan bidang kerjasama oleh ASEAN adalah bidang jasa. Bidang ini menjadi sangat penting, hal ini disebabkan dengan bidang ini ASEAN mampu meningkatkan sebanyak 40\% sampai 50\% PDB setiap tahunnya mengalami peningkatan. 


\section{Strategi Pemerintah Kota Bandung Mengembangkan Industri Kreatif dalam Menghadapi AEC dan AFTA}

Kota Bandung merupakan ibu kota Jawa Barat sekaligus salah satu kota yang dikenal dengan potensi ekonominya yang besar dan berkembang. Dengan jumlah penduduk yang didominasi oleh penduduk muda, kota ini memiliki berbagai komunitas kreatif dan produktif dalam berbagai bidang. Memiliki banyak kuliner dan tempat pariwisata, Bandung dianggap sebagai kota yang berpotensi sangat besar dalam ikut serta dalam pengembangan industri kreatif Indonesia. Hal tersebut disebabkan Bandung merupakan salah satu kota dengan penyumbang pendapatan daerah terbesar khususnya dalam bidang ekonomi kreatif. Maka, ekspektasi dari pemerintah pusat menjadi besar mengenai Kota Bandung dalam mengelola ekonominya. Tentu banyaknya dukungan dan nilai positif yang didapat menjadi acuan tersendiri bagi Kota Bandung. Sejalan dengan pendapatan ekonomi daerah yang besar, Pemerintah Kota Bandung menyiapkan berbagai kebijakan yang sesuai dan ikut meningkatkan ekonomi Kota Bandung.

Menjadi tren terbaru dalam pembangunan ekonomi sebuah negara, sektor ekonomi kreatif diusung utuk dapat membantu sebuah negara mencapai kepentingan nasionalnya. Bandung sebagai kota yang memiliki banyak peruguruan tinggi berkualitas, dan iklim masyarakat yang terbuka mengenai berbagai hal perubahan membuat kota ini memiliki kesempatan yang besar dalam pengembangan ekonomi kreatif. 
Dengan berbagai komunitas dan pemberdayaan manusia yang dilakukan oleh kota Bandung, ekonomi kreatif berhasil menyerap $11,877 \%$ total tenaga kerja manual. Hal ini juga disebabkan oleh anggapan bahwa ekonomi kreatif yang muncul baru-baru ini merupakan pekerjaan yang menjanjikan khususnya bagi anak muda. Bahkan keberadaan ekonomi kreatif bagi anak muda dijadikan sebagai upaya untuk mencari kegiatan yang diminatinya dan juga memberi masukan finansial bagi pribadinya. Ini sejalan dengan era globalisasi yang membawa kesan bahwa anak muda atau generasi milenial merupakan generasi yang dianggap sulit untuk menetap dalam satu bidang pekerjaan, karena dianggap tidak sesuai dengan minatnya dan ekonomi kreatif menjadi jawaban bagi golongan tersebut.

Menjadi kota yang berpengaruh dalam menyumbang pendapatan daerah untuk Indonesia, Kota Bandung mengalami pertumbuhan ekonomi sebesar $8,62 \%$ dari tahun 2008-2012 dan terus mengalami peningkatan setiap tahunnya. Walaupun sempat mengalami stagnansi pada tahun 2011-2012 disebabkan adanya kejenuhan dari berbagai bidang, Kota Bandung berhasil mengembalikan penghasilannya. Sub-kreatif yang menjadi salah satu andalan pembangunan ekonomi Kota Bandung ini menjadi landasan terbentuknya kota kreatif Bandung. Hal tersebut dikarenakan Kota Bandung memiliki budaya dan seninya yang kuat, karena dua aspek tersebut juga Kota Bandung dikenal dengan kota kuliner (Culinary City) dan menjadi tujuan para pencinta kuliner Indonesia. Memiliki berbagai bidang yang memberi 
sumbangan terbesar bagi penghasilan Indonesia, Kota Bandung bahkan dipilih sebagai Creative City oleh UNESCO pada tahun 2015 dalam bidang desain. Pemilihan sebagai kota desain ini dikarenakan Kota Bandung memiliki taman-taman kota dan bangunan seni yang mengikuti pola-pola Eropa.

Dalam menghadapi AEC Kota Bandung percaya akan mampu bersaing dengan negara-negara lain dalam pasar bebas. Salah satu yang dilakukan pemerintah Kota Bandung pada tahun 2016 di mana pemerintah Kota Bandung membangun PIPPK dalam otonomi daerahnya. PIPPK sendiri adalah "Program Inovasi Pembangunan dan Pemberdayaan Kewilayahan" di mana dengan program ini pemerintah Kota Bandung memberikan kewenangan kepada kelurahan untuk turut mengelola wilayahnya agar pembangunan daerah dapat berjalan dengan cepat dan berlandaskan aspirasi dari masyarakat (Atalia Praratya, 2017).Dengan konsep terbaru yang digencarkan oleh pemerintah Kota Bandung muncul harapan bahwa Kota Bandung akan menjadi kota yang memiliki ekonomi yang kuat. Konsep ini bertujuan untuk pemerintah kota memberikan alokasi dana kepada kecamatan atau daerah dengan kriteria tertentu. Kriteria ini termasuk mengenai luas wilayah, jumlah penduduk secara keseluruhan, dan jumlah penduduk miskin yang terdapat di daerah tersebut. Berbagai kriteria ini tentu ditujukan untuk membangun daerah sesuai dengan kebutuhannya, dan pemberian alokasi daerah ini tentu tidak terlepas dari campur tangan pemerintah kota yang harus terus memantau berbagai kegiatan yang dilakukan pemerintah daerah dengan alokasi 
dana yang diberikan.

Adanya konsep PIPPK tidak terlepas dari tujuan ekonomi kerakyatan yang dianut oleh Kota Bandung. Melalui adanya berbagai kegiatan yang dilakukan oleh pemerintah Kota Bandung, besar harapan adanya kekonsistenan terhadap pemanfataan sistem dalam padat karya. Tujuan ini juga diharapkan dapat membantu Kota Bandung untuk bersaing dalam AEC yang menyasar berbagai kota di Indonesia untuk mampu berkarya dan bersaing dalam kancah global. Untuk mengahadapi AEC Kota Bandung melakukan berbagai cara dan merancang berbagai strategi untuk mengelola sumber daya manusia yang dimiliki. Hal tersebut didukungn dengan adanya perancangan pembangunan yang mendorong pengembangan tata pemerintahan yang transparan dan akuntabel, yaitu Musyawarah Rencana Pembangunan. Adanya Musyawarah Rencana Pembangunan atau Musrenbag ini dijadikan sebagai acuan untuk terus membangun Kota Bandung dengan adanya masyarakat yang turut serta dengan cara mengusulkan berbagai kegiatan yang memudahkan rencana agar mudah diterima oleh masyarakat lainnya mengenai pembanguan.

Pemerintah Kota Bandung membuat banyak kegiatan serta kerjasama kota atau sister city dengan berbagai kota di luar negeri. Adapun strategi atau kegiatan yang dilakukan oleh pemerintah Kota Bandung dalam pembangunan ekonomi untuk mengahadapi AEC adalah, sebagai berikut: pertama, "Little Bandung" merupakan salah satu upaya yang dilakukan pemerintah Kota Bandung dalam memperkenalkan 
produk daerahnya ke mancanegara. Bukan hanya memperkenalkan produknya, dengan adanya Little Bandung besar harapan bahwa UKM Kota Bandung dapat berkembang dengan pesat tanpa harus tergantung dengan pemerintah pusat. Tidak terlepas dari itu hal ini dijadikan sebagai cara untuk untuk membangun brand Jawa Barat khususnya Kota Bandung agar dikenal dalam kalangan masyrakat luar negeri. Banyak dianggap sebagai diplomasi kreativitas, Little Bandung yang dibangun oleh pemerintah Kota Bandung memiliki tujuan untuk menyelesaikan masalah-masalah yang terkait dengan ekonomi atau segala pembangunan ekonomi Jawa Barat khususnya Kota Bandung.

Konsep dari adanya Little Bandung ini merupakan strategi marketing yang dilakukan oleh pemerintah Kota Bandung untuk memasarkan produk daerahnya agar dikenal oleh dunia internasional. Oleh karena itu ada tiga bagian dalam konsep Little Bandung yaitu: (1) Little Bandung Space dimana sektor yang menjadi tujuan untuk dipasarkan di luar negeri adalah sektor fesyen. Dimana berbagai produk pakaian khas butik Kota Bandung diperkenalkan serta dijadikan pendapatan secara ekonomi. (2) Little Bandung Wall dalam bagian kedua ini sektor yang ingin ditonjolkan adalah sektor kuliner. Di mana Kota Bandung memiliki kuliner khas yang dimiliki serta diminati oleh berbagai kalangan. Hal ini membuat pemerintah memanfaatkan kekhasan yang dimiliki oleh kuliner Bandung untuk dijadikan sebagai bidang yang dapat diperkenalkan kepada khalayak luas. (3) Little Bandung Mobile sektor yang terakhir ini merupakan upaya untuk 
memperkenalkan budaya yang dimiliki oleh Jawa Barat untuk dikenal kancah internasional (Novika Candra Astuti, 2018).

Berbagai kerjasamapun dilakukan oleh pemerintah Kota Bandung dengan berbagai negara juga dengan komunitas Indonesia di luar negeri atau diaspora. Kerjasama ini menghasilkan berbagai kerjasama yang terkait dengan pelaksanaan Little Bandung di kota yang bekerja sama dengan Bandung (Sister City). Seperti kerjasama yang dilakukan Bandung dengan Braunschweig, setelah 60 tahun bekerja sama akhirnya pemerintah mengambil langkah serius mengenai fungsi dari kerjasama tersebut. Hal ini terbukti dengan Little Bandung Festival yang dihadiri berbagai kalangan masyarakat Braunschweig. Selain dengan Braunschweig, Bandung juga melakukan hal yang serupa dengan Seoul, Korea Selatan. Di mana Dubes Indonesia untuk Korea Selatan membuka pavilion Indonesia pada Handmade Korea Summer 2017 di mana salah satu yang dipamerkan adalah koleksi barang-barang dari kota Bandung. Berdasarkan data Dinas Perdagangan dan Industri Kota Bandung, ekspor dari Kota Bandung ke Korea cenderung meningkat. Dimana tercatat pada tahun 2016 pendapatan Kota Bandung sebesar USD 13 juta dari sebelumnya sebesar USD 11 juta, dengan komoditi utama seperti alat kesehatan, fashion, furniture, dan makanan (Kedutaan Besar Republik Indonesia di Seoul, Republik Korea, 2018) Kedua, "Bandung Creative Hub" merupakan sebuah fasilitas publik yang dirancang oleh pemerintah Kota Bandung dengan tujuan memberikan ruang bagi industri kreatif serta bagi semua penggiat kreatif Kota 
Bandung. Adanya Bandung Creative Hub menjadi bentuk nyata dari pernyatan bahwa Bandung merupakan salah satu kota paling kreatif di Indonesia, bahkan pada pertemuan Creative Cities International yang diadakan di Yokohama, Jepang, Bandung menjadi "The Most Creative City in East Asia”. Tentu sandangan yang dibawa oleh Bandung sangat berkaitan erat dengan dibangunnya Bandung Creative Hub. Besar harapan bahwa fasilitas yang dapat digunakan siapa saja dari berbagai kalangan ini mampu menciptakan para kreator yang mampu ikut serta dalam pembagunan industri kreatif Kota Bandung di kemudian hari.

Berbagai faktor menjadi latar belakang dari terwujudnya yang memiliki berbagai ruang untuk pengembangan sektor kreatif dari mulai perpustakaan hingga ruang desain dan ruang kreatif lainnya. Adapun faktornya yaitu: (1) Masyarakat, dimana masyarakat Bandung mampu membuat produk dan layanan kreatif yang dibutuhkan oleh Bandung. Hal ini dikarenakan masyarakat Kota Bandung sudah mulai terbuka mengenai hal-hal yang masih dianggap sebagai baru oleh masyarakat lainnya. (2) Komunitas, bagian ini menjadi hal yang tidak bisa dipisahkan dari Bandung Creative Hub ini karena banyak pengunjung dan pengguna sarana dari Bandung Creative Hub adalah komunitas-komunitas kreatif Kota Bandung. (3) Tentunya berjalannya berbagai hal yang dapat dijadikan sebagai dasar bagi Kota Bandung adalah kebijakan. Disini kebijakan yang dibuat oleh pemerintah Kota Bandung dalam mendukung perkembangan industri kreatif sangat membantu berjalannya berbagai kegiatan yang sangat 
bermanfaat bagi masyarakat.

Selain itu banyak kerjasama-kerjasama yang dilakukan oleh Kota Bandung dengan negara-negara lain untuk mencapai taraf mempersiapkan diri dalam AEC atau pasar bebas. Pelaksanaan berbagai kegiatan ini tentu bukan hal yang mudah, Kota Bandung mengalami berbagai kegagalan dan hambatan nyata dalam menjalankan berbagai kegiatan, yaitu:

1. Kurangnya persiapan, hal ini menyebabkan banyak kesalahpahaman dalam mempersiapkan agenda yang direncanakan oleh pemerintah Kota Bandung. Salah satunya pelaksanaan Little Bandung di Penang, Malaysia yang pada tahun 2018 mengalami kegagalan dan harus ditutup dikarenakan tidak banyaknya transaksi yang dilakukan disana. Hal ini menjadi penting mengingat tujuan dari dibuatnya Little Bandung adalah untuk memperkenalkan industri dalam negeri khususnya industri kreatif yang dimiliki oleh Kota Bandung ke kancah internasional serta memberikan pemasukan daerah dengan terlaksananya.

2. Terbatasnya informasi mengenai berbagai kegiatan yang dilakukan oleh Kota Bandung dalam upaya pembangunan ekonomi. Hal ini menyebabkan masih banyaknya masyarakat Kota Bandung yang mengenal atau tidak tahu mengenai strategi apa saja yang dilakukan untuk mengembangkan perekonomian. Tentunya dalam pelaksanaan sebuah kebijakan haruslah seluruh 
elemennya ikut serta dalam kegiatan dan dengan ikut sertanya masyarakat dalam pembangunan ekonomi akan memudahkan pemerintah Kota Bandung untuk mencapai tujuannya. 


\section{DAFTAR PUSTAKA}

\section{BUKU}

Anak Agung, Banyu Perwita dan Yanyan Mochamad Yani. 2006. Pengantar Ilmu Hubungan Internasional. Bandung: PT Remaja Rosdakarya.

Bambang Cipto. Hubungan Internasional Di Asia Tenggara. 2010. Yogyakarta: Pustaka Pelajar.

Basuki Antariksa. 2016. Kebijakan Pembangunan Kepariwisataan. Malang: Intrans Publishing.

BEKRAF. Sistem Ekonomi Kreatif Nasional. Deputi Infrastuktur Badan Ekonomi Kreatif. 2016

Creswell, John W. 2010. Research Design: Pendekatan Kualitatif, Kuantitatif dan Campuran.Yogyakarta: Pustaka Pelajar.

Departemen Perdagangan Republik Indonesia. 2018. Dinas Pendidikan dan Kebudayaan. 1990.

Kamus Besar Bahasa Indonesia (Jakarta: Balai Pustaka) Hocking Brian dan Michael Smith. 1990. World Politics: An Introduction To International Relations. Hemel Hempsteads: Harvester Wheatsheaf.

I Gusti, Bagus Arjana. 2015. Geografi Pariwisata dan EkonomiKreatif. Jakarta: Rajawali Pers.

Jackson, Robert dan Georg Sorensen. 2013. Pengantar Studi Hubungan Internasional: Teori dan Pendekatan. Yogyakarta: Pustaka Pelajar.

Leo Agustino. 2008. Politik dan Kebijakan Publik. Bandung: AIPI.

Mohtar Mas'oed, 1990. Imu Hubungan Internasional: Displin dan Metodologi. Jakarta: LP3ES.

Moleong, Lexy J. 2007. Metode Penelitian Kualitatif. Bandung: PT Remaja Rosdakarya

Papp, S Daniel. 1997. Contemporary International Relations, 
Frameworks for Understanding United States of America: Allyn and Bacon.

Ratna Shofi Inayati. Impelemtasi AFTA: Tantangan Dan Pengaruhnya Terhadap Indonesia, Jurnal Penelitian Politik Lembaga Ilmu Pengetahuan Indonesia (LIPI) P-ISSN 1829-8001 e-ISSN 2502-7476 No.726/akred/P2MI-LIPI?04/2016

Sarah Anabarja. Kendala dan Tantangan Indonesia Dalam mengimplementasikan ASEAN Free Trade Area Menuju Terbentuknya ASEAN Economic Community

Sugiyono. 2011. Metode Penelitian Kuantitatif dan Kualitatif dan $R \& D$. Bandung: Alfabeta.

T May Rudi, Teori, Etika dan Kebijakan Internasional. 1995. Bandung: Angkasa.

Togar M. Simatupang, Gatot Yudoko, Yuanita Handayati, dkk. Analisis Kebijkan Pengembangan Industri Kreatif di Kota Bandung. Jurnal Manajemen Teknologi Volume 8 Number 1 2018.

Tonny Dian Effendi. 2011. Diplomasi Publik Jepang, Perkembangan dan Tantangan. Bogor: Ghalia Indonesia.

Tim Indonesia Design Power Departemen Perdagangan RI, Pengembangan Ekonomi Kreatif Indonesia 2025 "Cendikiawan, Pengusaha, Pemerintah. Jakarta: Kementerian Komunikasi dan Informatika Badan Informasi Publik Pusat Informasi Perekonomian.

Umar Suryadi Bakry. Ekonomi Politik Internasional Suatu Pengantar. 2015. Yogyakarta: Pustaka Penerbit Viotti, Mark dan Paul Kauppi. 1993. International Relations Theory. Allyn \& Bacon: Massachusetts.

\section{SUMBER INTERNET}

ASEAN Economic Community Blueprint, http:www.//asean.org, diunduh dari www.asean.org diakses pada 5 Februari 2018, Pkl. 15.00 WIB.

www.asean.org, ASEAN Economic Community (AEC), diunduh dari http://www.asean.org/storage/2012/05/56.-December-2015- 
Factinternet, 5

Februari 2018, Pkl. 15.10 WIB.

www.bppk.kemekeu.go.id, G.T Suroso dan Widyaiswara, Masyarakat Ekonomi ASEAN (MEA) dan Perekonomian Indonesia, diunduh dari http://www.bppk.kemenkeu.go.id/publikasi/artikel/150artikel- keuangan-umum/20545-masyarakat-ekonomi-aseanmea-dan- perekonomian-indonesia, internet, 7 Februari 2018, Pkl. 13.07 WIB.

www.antaranews, UNESCO umumkan Bandung masuk dalam jaringan kota kreatif, diunduh dari https://www.antaranews.com/ berita/534718/unescoumumkan-bandung-masuk-dalam-jaringan-kota-kreatif

Basuki Antariksa, "Konsep Ekonomi Kreatif: Peluang dan Tantangan dalam Pembangunan di Indonesia", Hasil Penelitian dan Pengembangan Kementerian Pariwisata Republik Indonesia, (2012) internet, 27 Januari 2018, www.kemenpar.go.id/zona/kreatif.

Piet Thabo Tshetlo, "An Analysis of The Implementation of The South Africa-China Bilateral Agreement: A Case Study of The South African Agricultural Technology Demonstration Centre", submitted in accordance with the requirement for the degree of Master of Administration, University of South Africa, internet, 3 Februari

2018.

Dhorifi Zumar. Pentingnya Ekonomi Kreatif Bagi Indonesia. Lokomotif Ekonomi Kreatif 2008 diakses http://ekonomikreatif.blogspot.com/2008/11/pentingnya-ekonomi-kreatifbagi.html pada 18 Oktober 2018, Pkl. 15.00 WIB.

Luh Made Suryagita Widianggastra, Masyarakat Ekonomi ASEAN Solusi Atau Bencana?, 2018diakses https://kumparan.com/gita- anggastra/masyarakat-ekonomiasean-solusi-atau-bencana pada 6 November 2018, Pkl. 15.10 WIB.

Kementerian Luar Negeri, Selayang Pandang ASEAN, diunduh dari www.kemlu.org.id, diakses pada 17 Oktober 2018, Pkl. 15.00 WIB. 
Pemerintah Kota Bandung. Diakses dari

https://portal.bandung.go.id/pemerintahan/struktur-

organisasi- pemerintah-kota-bandung, 19 Oktober, Pkl. 15.00 WIB.

Togar M. Simatupang, Perkembangan Industri Kreatif, Institut Teknologi Bandung diakses di http://www.academia.edu/2876337/Industri_Kreatif_Jawa_B arat pada 18 Oktober 2018, Pkl. 16.00 WIB.

Valentina Montalto, "Why The EU and China Should Further Engage in Business Cooperation and Trade in The Field of Cultural and Creative Industries" Tafter Journal No.34 (April 2011) internet, 18 Januari 2018, Pkl. $16.00 \quad$ WIB. www.tafterjournal.it 